\title{
CB1 LIGANDS MODULATION OF LEARNING AND MEMORY OF OBX RATS
}

\author{
Miroslav Marinov ${ }^{1}$, Margarita Ivanova ${ }^{1}$, Stiliana Belcheva ${ }^{2}$, Iren Belcheva ${ }^{3}$, Negrin Negrev ${ }^{4}$, \\ Roman Tashev ${ }^{5}$ \\ ${ }^{1}$ Department of Physiology and Pathophysiology, Faculty of Medicine, \\ Medical University of Varna \\ ${ }^{2}$ Faculty of Pre-School and Primary School Education, \\ Sofia University "St. Kliment Ohridsky" \\ ${ }^{3}$ Institute of Neurobiology, Bulgarian Academy of Sciences \\ ${ }^{4}$ Medical College of Varna, Medical University of Varna \\ ${ }^{5}$ Department of Pathophysiology, Medical University of Sofia; Institute of Neurobiology, \\ Bulgarian Academy of Sciences
}

\begin{abstract}
AIM: The brain endocannabinoid system has been shown to play a role in learning and memory processes, although the exact mechanisms by which it interferes in these processes are not well established. We aimed at studying the effects of $\mathrm{CB} 1$ receptor ligands on learning and memory of rats with an experimental model of depression - olfactory bulbectomy (OBX). Materials and Methods. Cannabinoid CB1 receptor agonist HU-210 (5 $\mu \mathrm{g})$ and cannabinoid CB1 receptor antagonist SR 141716A (3 $\mu \mathrm{g})$ were microinjected i.c.v. in male Wistar rats with an olfactory bulbectomy (OBX) model of depression. A passive avoidance task (stepthrough) was used as a test for learning and memory.

RESULTS: In the non-OBX group, HU-210 impaired learning and memory processes expressed by the shortened latency time on the retention tests ( 3 hours and 24 hours after training) and by the decreased percentage of rats that have reached the learning criterion, as compared to the saline-treated controls. SR 141716A did not affect significantly the performance of rats in the step-through task. In the OBX rats, HU-210 prolonged the latency time as compared to the saline-treated OBX controls, while SR 141716A did not affect significantly the OBX-related learning and memory deficits.
\end{abstract}

CONCLUSION: The findings suggest a complex modulatory effect of the CB1 receptor agonist on learning and memory processes in non-OBX and $\mathrm{OBX}$ rats.

Keywords: learning, memory, CB1 cannabinoid receptors, step-through, rat, olfactory bulbectomy

Address for correspondence:

Department of Physiology and Pathophysiology

Medical University of Varna

55, M. Drinov Str.

9000 Varna, Bulgaria

Tel: 052677051

e-mail:mdmarinov@gmail.com

Received: May 20, 2016

Accepted: August 29, 2016

\section{INTRODUCTION}

The endocannabinoid system is a lipid signalling system in the brain that consists of endocannabinoids, cannabinoid receptors and the enzymes involved in the endocannabinoid biosynthesis or inactivation (22). Endocannabinoids are derivatives of arachidonic acid and the two major endogenous ligands are anandamide ( $\mathrm{N}$-arachidonoylethanolamine) and 2-arachidonoylglycerol. There are two 
Miroslav Marinov, Margarita Ivanova, Stiliana Belcheva et al.

types of cannabinoid receptors (CB1 and $\mathrm{CB} 2)$, which belong to the family of G-protein-coupled receptors (22). Endocannabinoids are synthesized postsynaptically from lipid membrane precursor molecules and act presynaptically on CB1 receptors by modulating the release of neurotransmitters in the central nervous system. The cannabinoid receptor type 1 (CB1) as well as endocannabinoids are present in memoryrelated brain areas and have been implicated in the modulation of memory processes $(9,20)$.

While cannabinoidomimetics have been claimed to induce memory deficits in both humans and animals the experimental data about the effects of CB1 receptor ligands on learning and memory processes are contradictory. The pharmacological activation of CB1 receptors has been shown to impair short-term memory, its consolidation and the formation of long-term memory (24). In addition, the inhibition of the endocannabinoid system by application of CB1 receptor antagonists improved memory in rats $(11,24)$. However, the increased level of anandamide in mice lacking fatty acid amide hydrolase did not affect the working memory in a water maze task (29).

The endocannabinoid system has been shown to play an important role in the pathogenesis of depressive disorders, which are known to be accompanied by impaired cognitive functions, including memory deficits $(10,18)$. The $\mathrm{CB} 1$ receptor ligands are now investigated as potential anti-depressant agents although additional studies have to reveal their involvement in the mechanisms of depression (21).

Bilateral olfactory bulbectomy (OBX) is an experimental model of depression which produces in rodents a syndrome with behavioral, neurochemi$\mathrm{cal}$, and structural abnormalities similar to those observed in human depression (28). Taking into consideration the above-mentioned data, the aim of our study was to examine the effect of centrally administered CB1 receptor ligands on learning and memory of rats with an OBX model of depression, using the one-way passive avoidance test.

\section{MATERIALS AND METHODS}

\section{Animals}

The experiments were carried out on 76 male Wistar rats (200-220 $\mathrm{g}$ at the time of surgery) the rules of the Ethics Committee of the Institute of Neurobiology, Bulgarian Academy of Sciences.

Experimental Model of Depression - Bilateral Olfactory Bulbectomy (OBX)

Bilateral OBX was performed according to the method described by Kelly et al. (14). Animals were anesthetized with Calypsol (50 mg/kg i.p.). The surgical procedure was performed with a stereotaxic apparatus (Stoelting, USA). The coordinates of the olfactory bulbs were determined according to the stereotaxic atlas of Pellegrino and Cushman (23). The bulbs were aspirated with a stainless needle attached to a water pump. After the surgery, the rats were housed in groups of two and were handled and weighed daily during a 15-day period. The sham operation was performed in the same way as in the case of olfactory bulbectomy without the removal of the olfactory bulbs.

Stereotaxic Implantation and Drug Injection into Ventriculus Ventrolateralis Dexter

After the anesthesia the rats were placed in the stereotaxic apparatus) and guide cannulae were implanted into ventriculus ventrolateralis dextra based on coordinates from obtained from the stereotaxic atlas of Pellegrino and Cushman (23).

HU-210 (Tocris) and SR 141716A (Tocris) were dissolved ex tempore in a 1:19 solution of dimethyl sulfoxide/ $0.9 \%$ saline and $1 \mu \mathrm{l}$ of drug solution $(\mathrm{pH}$ 7.4) was infused i.c.v. $5 \mathrm{~min}$ before the behavioral test. Following the termination of the experiments and immediately prior to sacrifice rats were injected with $1 \mathrm{ml} 2 \%$ fast green dye through the injection cannula for verification of cannula placement into ventriculus ventrolateralis dextra.

\section{One-Way Passive Avoidance Test (Step-Through)}

In the passive avoidance task the rat must learn to remain in a brightly lit compartment and not enter the preferred dark compartment to avoid a mild foot shock. One training trial and two retention tests were conducted according to the method developed by Kurtz and Pearl (16) and modified by Bures and Buresova (3). The training trial was started by placing the rat in the light compartment. Once the rat had entered the dark compartment, the guillotine door was closed and an electric shock $(0.3-0.35 \mathrm{~mA}$ for 3 s) was delivered to the animal through the grid floor. 
Each rat underwent one trial. Retention tests (no shocks) were performed $3 \mathrm{~h}$ and $24 \mathrm{~h}$ after the acquisition trial. At that time, the animals were returned to the light compartment, and step-through latency was estimated by measuring the length of time (latent time) for the rat to move to the dark compartment. A maximum latency of 180 seconds was used as a criterion for learning.

\section{Statistical Analysis}

One-way ANOVA was used to process the data obtained for learning and memory. ANOVA data were further analyzed by post hoc t-test where appropriate. Analysis of the passive avoidance data was performed using $\chi^{2}$ test.

\section{RESULTS}

Oneway ANOVA of the effects of the ligands on the latent time in non-OBX rats demonstrated a significant effect for factor "drug" on the $3^{\text {rd }}$ hour $\left(\mathrm{F}_{2,35}=5.68 ; \mathrm{P} \leq 0.01\right)$ and $24^{\text {th }}$ hour $\left(\mathrm{F}_{2,35}=7.73 ; \mathrm{P} \leq 0.01\right)$.

Post-hoc comparisons showed that HU-210 significantly decreased the latent time at the $3^{\text {rd }}$ hour $(\mathrm{t}=1.95 ; \mathrm{P} \leq 0.05)$ and the $24^{\text {th }}$ hour $(\mathrm{t}=2.50 ; \mathrm{P} \leq 0.01)$, and showed a tendency to decrease the percentage of rats that have reached the learning criterion on the $3^{\text {rd }}$ hour $\left(\chi^{2}=1.510 ; \mathrm{P}=\mathrm{NS}\right)$ and $24^{\text {th }}$ hour $\left(\chi^{2}=2.667\right.$; $\mathrm{P}=\mathrm{NS}$ ) in the retention test as compared to the saline-treated control rats (Fig. 1, Table 1). The microinjections of SR 141716A did not affect significantly the tested parameters in the non-OBX rats, as compared to the saline-treated controls (Fig. 1., Table 1.).

ANOVA of the effects of the ligands on the latent time of the OBX rats demonstrated a significant effect for factor "drug" on the $3^{\text {rd }}$ hour $\left(\mathrm{F}_{2,29}=13.93\right.$; $\mathrm{P} \leq 0.001)$ and $24^{\text {th }}$ hour $\left(\mathrm{F}_{2,29}=9.00 ; \mathrm{P} \leq 0.001\right)$.

Post-hoc comparisons showed that HU-210 significantly increased the latent time in the OBX rats at the $3^{\text {rd }}$ hour $(\mathrm{t}=4.20 ; \mathrm{P} \leq 0.001)$ and the $24^{\text {th }}$ hour $(\mathrm{t}=3.49 ; \mathrm{P} \leq 0.001)$, and showed a tendency to increase the percentage of OBX rats that have reached the learning criterion on the $3^{\text {rd }}$ hour $\left(10 \%, \chi^{2}=1.053\right.$; $\mathrm{P}=\mathrm{NS})$ and $24^{\text {th }}$ hour $\left(20 \%, \chi^{2}=2.222\right.$; $\left.\mathrm{P}=\mathrm{NS}\right)$ as compared to the OBX saline-treated group (Fig. 2, Table 2). As compared to the sham-operated rats, HU210 injected in OBX rats significantly reduced the latent time at the $3^{\text {rd }}$ hour $(\mathrm{t}=3.59 ; \mathrm{P} \leq 0.001)$ and the $24^{\text {th }}$ hour ( $\mathrm{t}=3.08$; $\mathrm{P} \leq 0.01)$ (Fig. 2., Table 2.).
The microinjections of SR 141716A did not affect significantly the tested parameters in the OBX rats, as compared to the respective saline-treated OBX controls. However, the comparison to the sham-operated rats revealed a significant decrease of the latent time on the $3^{\text {rd }}$ hour $(\mathrm{t}=8.31 ; \mathrm{P} \leq 0.001)$ and the $24^{\text {th }}$ hour $(t=7.98 ; \mathrm{P} \leq 0.001)$ (Fig. 2, Table 2).

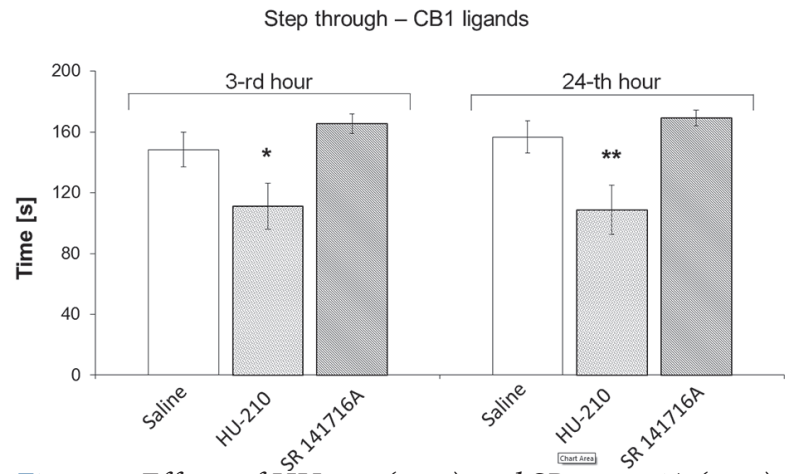

Figure 1. Effects of HU-210 (5 $\mu \mathrm{g})$ and SR 141716A (3 $\mu \mathrm{g})$, microinjected i.c.v. in non-OBX rats on the latent time on the $3^{\text {rd }}$ and $24^{\text {th }}$ hours (step-through test) $n=12 .{ }^{*} P \leq 0.05$, ${ }^{*} P \leq 0.01$ asterisks depict drug vs. saline-treated controls. Means ( \pm S.E.M.) are presented.

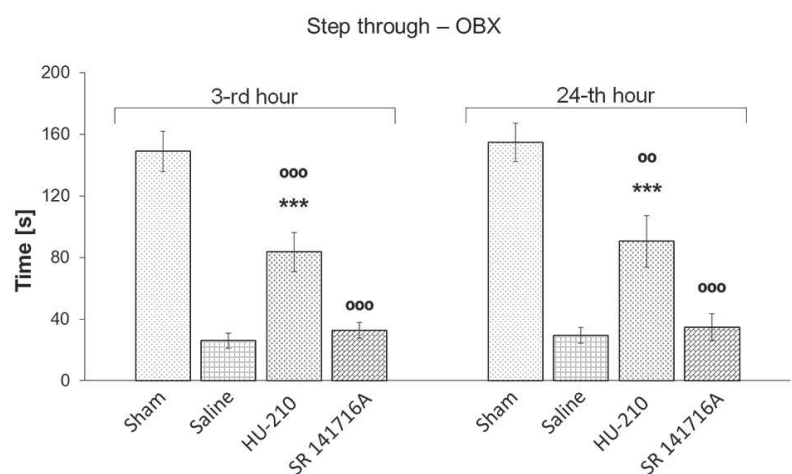

Figure 2. Effects of HU-210 (5 $\mu \mathrm{g})$ and SR 141716A (3 $\mu \mathrm{g})$, microinjected i.c.v. in $\mathrm{OBX}$ rats on the latent time on the $3^{\text {rd }}$ and $24^{\text {th }}$ hours (step-through test) $n=10 .{ }^{* * *} P \leq 0.001$, asterisks depict ligand vs. saline-treated $O B X$ controls; ${ }^{00} P \leq 0.01,{ }^{\circ 00} P \leq 0.001$, circles depict $O B X$ vs. sham-operated animals. Means ( \pm S.E.M.) are presented.

\section{DISCUSSION}

Our results showed that the acute i.c.v. administration of CB1 receptor agonist HU-210 impaired learning and memory of rats, tested in a step-trough test. The effect was expressed as a decrease of the latent time on the $3^{\text {rd }}$ and $24^{\text {th }}$ hour of the retention test 
Miroslav Marinov, Margarita Ivanova, Stiliana Belcheva et al.

Table 1. Effects of HU-210 (5 $\mu \mathrm{g})$ and SR 141716A (3 $\mu \mathrm{g})$, microinjected i.c.v. in rats, on the latent time (step-through). ${ }^{*} P \leq 0.05,{ }^{*} P \leq 0.01$ asterisks depict drug vs. saline-treated controls. Means ( \pm S.E.M.) are presented.

\begin{tabular}{|l|c|c|c|c|c|c||}
\multirow{2}{*}{ Groups } & \multicolumn{3}{c|}{ Retention test } \\
\cline { 2 - 7 } & $\begin{array}{c}\text { Latent time } \\
\bar{\chi} \pm S E M\end{array}$ & $\begin{array}{c}\text { \% reaching } \\
\text { criterion }\end{array}$ & $\begin{array}{c}\text { Learning } \\
\text { criterion }\end{array}$ & $\begin{array}{c}\text { Latent time } \\
\bar{\chi} \pm S E M\end{array}$ & $\begin{array}{c}\text { \% reaching } \\
\text { criterion }\end{array}$ & $\begin{array}{c}\text { Learning } \\
\text { criterion }\end{array}$ \\
\hline $\begin{array}{l}\text { Saline } \\
\mathrm{n}=12\end{array}$ & $148.33 \pm 11.48$ & $58 \%$ & $(7 / 12)$ & $156.67 \pm 10.47$ & $67 \%$ & $(8 / 12)$ \\
\hline $\begin{array}{l}\mathrm{HU}-210 \\
\mathrm{n}=12\end{array}$ & $11.25 \pm 15.16^{*}$ & $33 \%$ & $(4 / 12)$ & $108.75 \pm 16.09 * *$ & $33 \%$ & $(4 / 12)$ \\
\hline $\begin{array}{l}\mathrm{SR} 141716 \mathrm{~A} \\
\mathrm{n}=12\end{array}$ & $165.42 \pm 6.56$ & $67 \%$ & $(8 / 12)$ & $169.17 \pm 5.14$ & $67 \%$ & $(8 / 12)$ \\
\hline
\end{tabular}

Table 2. Effects of HU-210 (5 $\mu \mathrm{g})$ and SR 141716A (3 $\mu \mathrm{g})$, microinjected i.c.v. in OBX rats, on the latent time (stepthrough). ${ }^{* *} P \leq 0.001$ asterisks depict ligand vs. saline-treated $O B X$ controls; ${ }^{\circ *} P \leq 0.001$ circles depict $O B X v s$. sham-operated animals.

\begin{tabular}{|c|c|c|c|c|c|c|}
\hline \multirow{3}{*}{ Groups } & \multicolumn{6}{|c|}{ Retention test } \\
\hline & \multicolumn{3}{|c|}{ 3rd hour } & \multicolumn{3}{|c|}{ 24th hour } \\
\hline & $\begin{array}{l}\text { Latent time } \\
\bar{z} \pm S E M\end{array}$ & $\begin{array}{l}\% \text { reaching } \\
\text { criterion }\end{array}$ & $\begin{array}{l}\text { Learning } \\
\text { criterion }\end{array}$ & $\begin{array}{l}\text { Latent time } \\
\bar{z} \pm S E M\end{array}$ & $\begin{array}{l}\text { \% reaching } \\
\text { criterion }\end{array}$ & $\begin{array}{l}\text { Learning } \\
\text { criterion }\end{array}$ \\
\hline $\begin{array}{l}\text { Sham-operated } \\
\mathrm{n}=10\end{array}$ & $148.90 \pm 13.03$ & $60 \%$ & $(6 / 10)$ & $154.80 \pm 12.29$ & $60 \%$ & $(6 / 10)$ \\
\hline $\begin{array}{l}\text { OBX } \\
n=10\end{array}$ & $26.00 \pm 4.93^{\circ o o}$ & $0 \%$ & $(0 / 10)$ & $29.30 \pm 5.17^{\text {ooo }}$ & $0 \%$ & $(0 / 10)$ \\
\hline $\begin{array}{l}\text { OBX }+ \text { HU }-210 \\
n=10\end{array}$ & $83.50 \pm 12.76^{\star * *}$ & $10 \%$ & $(1 / 10)$ & $90.60 \pm 16.70^{\star * *}$ & $20 \%$ & $(2 / 10)$ \\
\hline $\begin{array}{l}\mathrm{OBX}+\mathrm{SR} \\
141716 \mathrm{~A} \\
\mathrm{n}=10\end{array}$ & $32.70 \pm 5.07$ & $0 \%$ & $(0 / 10)$ & $34.70 \pm 8.70$ & $0 \%$ & $(0 / 10)$ \\
\hline
\end{tabular}

and a decrease of the number of rats that reached the learning criteria. The infusion of the CB1 receptor antagonist SR 141716A did not affect significantly the performance of rats in the step-through task. This finding is in accordance with most of the literature data, showing that cannabinoids tend to disrupt memory.

Experiments on the endocannabinoid system have revealed that its proper functioning is necessary for the neurobiological mechanisms responsible for some learning and memory processes. There are numerous reports that the administration of cannabinoid agonists impairs memory $(7,12,13)$. Works have also found memory improvement employing selective CB1 antagonists $(17,27)$. Compared with cannabinoid agonists, studies with selective $\mathrm{CB} 1$ antago- nists are less consistent, with some showing memory impairment (2), and others no effect at all $(6,7)$. Recent reports revealed that the modulatory effects of cannabinoid receptors on cognitive functions are dependent on many factors, including dosage, type of the ligand and the brain area where it exerts its action $(1,8)$.

As $\mathrm{CB} 1$ receptors are widely distributed in the CNS, it is difficult to explain the effect observed in our study of the cannabinoid CB1 agonist, infused i.c.v., on memory processes. The endocannabinoid system has been implicated in the regulation of longterm potentiation (LTP) and synaptic plasticity. Long-term potentiation in the hippocampal CA1 regions is regarded to be the cellular substrate of learning and memory. Studies conducted on hippocam- 
pal slices have shown that exogenously applied cannabinoids act at CB1 receptors to prevent LTP (7). It was also found that the endocannabinoids, acting as retrograde messengers for presynaptic inhibition, can act to both strengthen and weaken the connections between neurons. They strengthen connections by decreasing presynaptic inhibition (30), and weaken connections by decreasing presynaptic excitation (15).

A significant impairment of learning and memory-related behavior was induced in rats after olfactory bulbectomy (OBX), as measured by different tests, including passive avoidance task $(26,28)$. In the present study HU-210 showed a memory improving effect on the memory deficits of OBX rats, expressed as an increase of the latent time on $3^{\text {rd }}$ and $24^{\text {th }}$ hour of the retention test and an increase of the rats that reached the learning criteria, while SR 141716A did not produce any significant effects on rats performance. These findings are consistent with our previous research on the effects of cannabinoid ligands on the performance of OBX-rats in an active-avoidance test (shuttle box) (19). A positive effect, improving the locomotor deficits induced by the bulbectomy has been reported by Rodríguez-Gaztelumendi et al. (25) after acute intraperitoneal administration of $\Delta^{9}$ tetrahydrocannabinol. Similarly, chronic treatment with fluoxetine (subcutaneous) abolished the OBXinduced hyperactivity in the open-field test. Our results do not allow us to explain the behavioral effect of the CB1 receptor agonist in the step-through task. It could be suggested that the reported endocannabinoid-elicited decrease of inhibitory neurotransmission which was shown to facilitate hippocampal LTP by disinhibiting pyramidal neurons $(4,5)$ may also contribute to the memory-enhancing effects of the $\mathrm{CB} 1$ receptor agonist.

\section{CONCLUSION}

The results of the presents study showed that the acute i.c.v. infusion of $\mathrm{CB} 1$ receptor agonist HU$210(5 \mu \mathrm{g})$ impaired learning and memory of nonOBX rats, tested in a step-trough test. by. However, memory-improving effects were demonstrated upon administration of HU-210 in rats with an OBX model of depression. SR 141716A did not produce any significant effect neither in non-OBX group nor in OBX-group. It could be suggested that the neuro- chemical and neurodegenerative changes following bulbectomy might account for the opposite effects of the cannabinoid agonist on the performance of rats in the passive avoidance test.

\section{REFERENCES}

1. Abush H., I. Akirav. Cannabinoids modulate hippocampal memory and plasticity.- Hippocampus, 2010, 20, 1126-1138.

2. Arenos J. D., R. E. Musty, D. J. Bucci. Blockade of cannabinoid CB1 receptors alters contextual learning and memory.- Eur. J. Pharmacol., 2006, 539, 177-183.

3. Bures J., W. Buresova. Cortical spreading depression as a memory disturbing factor.- J. Comp. Physiol. Psychol., 1963, 56, 268-272.

4. Carlson G., Y. Wang, B. E. Alger. Endocannabinoids facilitate the induction of LTP in the hippocampus.- Nat. Neurosci., 2002, 5, 723-724.

5. Chevaleyre V., P. E. Castillo. Endocannabinoid-mediated metaplasticity in the hippocampus.- Neuron, 2004, 43, 871-881.

6. Da S., R. N. Takahashi. SR 141716A prevents delta 9-tetrahydrocannabinol-induced spatial learning deficit in a Morris-type water maze in mice.- Prog. Neuropsychopharmacol. Biol. Psychiatry, 2002, 26, 321-325.

7. Davies S. N., R. G. Pertwee, G. Riedel. Functions of cannabinoid receptors in the hippocampus.- Neuropharmacology, 2002, 42, 993-1007.

8. De Oliveira Alvares L., B. P. Genro, F. Diehl, J. A. Quillfeldt. Differential role of the hippocampal endocannabinoid system in the memory consolidation and retrieval mechanisms.- Neurobiol. Learn. Mem., 2008, 90, 1-9.

9. Freund T. F., I. Katona, D. Piomelli. Role of endogenous cannabinoids in synaptic signaling.- Physiol. Rev., 2003, 83, 1017-1066.

10. Gohier B., L. Ferracci, S. A. Surguladze, E. Lawrence, W. El Hage, M. Z. Kefi et al. Cognitive inhibition and working memory in unipolar depression.- J. Affect. Disord., 2009, 116, 100-105.

11. Hampson R. E., A. J. Sweatt, A. V. Goonawardena, D. Song, R. H. Chan, V. Z. Marmarelis et al. Memory encoding in hippocampal ensembles is negatively influenced by cannabinoid CB1 receptors.- Behav. Pharmacol., 2011, 22, 335-346. 
Miroslav Marinov, Margarita Ivanova, Stiliana Belcheva et al.

12. Hampson R. E., S. A. Deadwyler. Role of cannabinoid receptors in memory storage.- Neurobiol. Dis., 1998, 5, 474-482.

13. Hernández-Tristán R., C. Arévalo, S. Canals, M. L. Leret. The effects of acute treatment with delta9THC on exploratory behaviour and memory in the rat.- J. Physiol. Biochem., 2000, 56, 17-24.

14. Kelly J. P., A. S. Wrynn, B. E. Leonard. The olfactory bulbectomized rat as a model of depression: an update.- Pharmacol. Ther., 1997, 74, 299-316.

15. Kreitzer A. C., W. G. Regehr. Retrograde inhibition of presynaptic calcium influx by endogenous cannabinoids at excitatory synapses onto Purkinje cells.- Neuron, 2001, 29, 717-727.

16. Kurtz K. H., J. Pearl. The effects of prior fear experiences on acquired-drive learning.- J. Comp. Physiol. Psychol., 1960, 53, 201-206.

17. Lichtman A. H. SR 141716A enhances spatial memory as assessed in a radial-arm maze task in rats.Eur. J. Pharmacol., 2000, 404, 175-179.

18. Marazziti D., G. Consoli, M. Picchetti, M. Carlini, L. Faravelli. Cognitive impairment in major depression.- Eur. J. Pharmacol., 2010, 626, No 1: 83-86.

19. Marinov M., M. Ivanova, S. Belcheva, I. Belcheva, R. Tashev. Effects of acutely applied cannabinoid CB1 ligands on learning and memory in rats with a model of depression.- Compt. Rend. Acad. Bulg. Sci., 2013, 6, 1331-1338.

20. Marsicano G., R. Kuner.- In: Cannabinoids and the Brain. A. Kofalvi, ed. Springer, New York, 2008, 161-202.

21. Patel S., C. J. Hillard. Role of endocannabinoid signaling in anxiety and depression.- Curr. Top. Behav. Neurosci., 2009, 1, 347-371.

22. Pazos M. R., E. Núñez, C. Benito, R. M. Tolón, J. Romero. Functional neuroanatomy of the endocannabinoid system.- Pharmacol. Biochem. Behav., 2005, 81, 239-247.

23. Pellegrino L., A. Cushman. A Stereotaxic Atlas of the Rat Brain. Appleton-Century-Crofts, New York, USA, 1967.

24. Riedel G., S. N. Davies.- In: Cannabinoids. R. G. Pertwee, ed. Handb. Exp. Pharmacol., SpringerVerlag, Berlin, 168, 2005, 445-477.

25. Rodríguez-Gaztelumendi A., M. L. Rojo, A. Pazos, A. Díaz. Altered CB receptor-signaling in prefrontal cortex from an animal model of depression is reversed by chronic fluoxetine.- J. Neurochem., 2009, 108, No 6, 1423-1433.

26. Song C., B. E. Leonard. The olfactory bulbectomised rat as a model of depression.- Neurosci. Biobehav., Rev., 2005, 29, 627-647.

27. Takahashi R. N., F. A. Pamplona, M. S. Fernandes. The cannabinoid antagonist SR141716A facilitates memory acquisition and consolidation in the mouse elevated T-maze.- Neurosci. Lett., 2005, 380, 270-275.

28. Tashev R., M. Ivanova, T. Toromanov, M. Marinov, S. Belcheva, I. Belcheva Olfactory bulbectomy impairs active and passive avoidance learning in rats.Compt. Rend. Acad. Bulg. Sci., 63, 2010, 617-620.

29. Varvel S. A., B. F. Cravatt, A. E. Engram, A. H. Lichtman. Fatty acid amide hydrolase (-/-) mice exhibit an increased sensitivity to the disruptive effects of anandamide or oleamide in a working memory water maze task.- J. Pharmacol. Exp. Ther., 2006, 317, 251-257.

30. Wilson R. I., R. A. Nicoll. Endogenous cannabinoids mediate retrograde signalling at hippocampal synapses.- Nature, 2001, 410, 588-592. 